\title{
Potensi Dedak Padi yang Difermentasi dengan Enzim Fitase dalam Pakan Basal Terhadap Kolesterol Total Darah Ayam Petelur
}

\section{The Potency of Rice Bran Fermented by Phytase Enzyme in Basal Feed on The Total Blood Cholesterol Level in Laying Hen}

\author{
Yulia Nurfitri ${ }^{1}$, Mirni Lamid ${ }^{2}$, Margareth Gandul Atik Yuliani ${ }^{3}$, Mohamad Anam Al- \\ Arief $^{2}$, Retno Sri Wahyuni ${ }^{3}$, Eduardus Bimo Aksono ${ }^{3}$ \\ ${ }^{1}$ Mahasiswa, ${ }^{2}$ Departemen Peternakan, ${ }^{3}$ Departemen Ilmu Kedokteran Dasar \\ Veteriner, Fakultas Kedokteran Hewan, Universitas Airlangga \\ Corresponding author: yulia.nurfitri-2015@fkh.unair.ac.id
}

\begin{abstract}
This study aimed to evaluate the potential of rice bran fermented by the enzyme phytase in basal feed to the total blood cholesterol level of laying hen. This research use an experimental method in vivo with a completely randomized design consisting of six treatments and four replications in each treatment. The experimental animals used 24 48-week-old female laying hen strain Isa Brown. The treatment wa given basal feed substituted with different percentage of fermented rice bran by phytase enzyme and 2\% lemuru fish oil supplementation. In this research the amount of fermented rice bran by phytase enzyme substituted on basal feed was: treatment P0 (-) (0\%), PO (+) (0\%), P1 $(5 \%)$, P2 (10\%) P3 (15\%) and P4 (20\%). The results of the statistical analysis showed that there are no significant differences $(p>0.05)$ on total blood cholesterol levels in all treatments. The conclusion of the research is that rice bran fermented by phytase enzymes tends to decrease total blood cholesterol levels in laying hen.
\end{abstract}

Keywords: Phytase enzyme, rice bran, blood cholesterol

Received: 08-09-2020

Revised: 09-10-2020

Accepted: $10-11-2020$

\section{PENDAHULUAN}

Ayam petelur merupakan komoditas ternak unggas sebagai penghasil telur dan daging. Ternak ini berperan penting dalam mendukung ketersediaan sumber protein hewani yang murah dan mudah didapat. Usaha dibidang peternakan ayam petelur sebagai sumber pendapatan yang banyak diminati di daerah pedesaan dan di perkotaan baik secara moderen maupun tradisional. Dirjen Peternakan dan Kesehatan Hewan 2018 melaporkan bahwa populasi ayam petelur di Indonesia meningkat setiap tahunnya. Peningkatan populasi tersebut mengindikasikan bahwa terjadi peningkatan konsumsi masyarakat terhadap produk panggan asal unggas (Wijaya dkk., 2013).
Kesadaran masyarakat akan kesehatan semakin tinggi, masyarakat menginginkan bahan pangan asal hewan khususnya unggas dengan kandungan rendah lemak seperti kolesterol dan trigliserida. Kolesterol adalah suatu komponen lemak yang berperan dalam pembentukan hormon, anak ginjal, testis dan ovarium. Kolesterol terdapat pada bahan pangan asal hewan seperti kuning telur, hati dan otak. Secara normal kolesterol diproduksi tubuh dalam jumlah yang tepat, namun dapat meningkat jumlahnya karena penambahan makanan yang berasal dari lemak hewani (Murray et al,. 2012). Bahan pangan yang mengandung kolesterol tinggi dapat menyebabkan gejala 
pankreatitis, perbesaran hati, dan meningkatkan konsentrasi very low density lipoprotein (VLDL) yang kemudian akan meningkatkan resiko arteriosklerosis, yang menyebabkan berbagai penyakit seperti stroke dan jantung koroner (Wijaya dkk,. 2013). Tinggi rendahnya kolesterol dalam tubuh dapat dipengaruhi oleh pakan yang dikonsumsi (Joseph dkk., 2002).

Penyusunan formulasi pakan sangat penting dalam usaha peternakan untuk menghasilkan pakan berkualitas dengan biaya semurah mungkin (Natsir dkk,. 2017). Penggunaan dedak padi oleh peternak sebagai pakan unggas hampir mencapai 15\% dalam ransum. Dedak padi memiliki kandungan nutrisi yang rendah dan kandungan serat kasar yang tinggi. Serat kasar yang terdiri dari selulosa, hemiselulosa dan lignin sebagian besar tidak dicerna oleh unggas dan bersifat sebagai pengganjal atau bulky (Wahju, 2004). Menurut Bidura dalam Witariadi dkk. (2014) dedak padi mengandung serat kasar berkisar 13,0 \% dan mengandung senyawa asam fitat. Asam fitat merupakan zat antinutrisi dalam bijibijan dan serealia yang dapat mengikat beberapa mineral yang penting dan membentuk senyawa kompleks dengan $\mathrm{P}, \mathrm{Mg}, \mathrm{Mn}, \mathrm{Zn}$, Fe, dan Ca. Adanya senyawa kompeks asam fitat dan mineral mengakibatkan unggas tidak dapat menggunakan mineral yang terdapat dalam biji-bijian secara maksimal (Lamid et al., 2014). Kandungan asam ammonium, vitamin dan mineral dalam padi juga rendah, sehingga penggunaan dedak padi pada ransum unggas harus dibatasi yaitu maksimal 20\% (Witariadi dkk, 2014).

Enzim fitase dapat mendegradasi asam fitat dan garamnya menyebabkan mineral yang terikat asam fitat tersedia secara bebas sehingga dapat diserap oleh tubuh (Reddy et al., 1982). Unggas tidak memiliki mikroba penghasil enzim fitase di dalam saluran pencernaannya, sehingga enzim fitase harus ditambahkan ke dalam ransum (Lamid et al., 2014). Menurut Mastika (2000) yang dikutip oleh Witariadi dkk. (2014), penambahan enzim biasanya dilakukan pada bahan pakan yang kecernaannya rendah, sehingga dapat meningkatkan penggunaan bahan pakan tersebut. Penambahan enzim kedalam ransum, seperti enzim fitase dapat memecah senyawa fitat pada dedak padi, sehingga penggunaannya dalam ransum dapat mengatasi kelemahan nutrisi dedak padi.

Penambahan minyak dalam ransum bertujuan untuk memperkaya sumber energi yang sangat dibutuhkan unggas. Minyak dalam ransum juga dapat menambah palatabilitas dan mengurangi sifat berdebu pada ransum yang berbentuk mash. Minyak ikan lemuru mengandung asam lemak tak jenuh omega-3 yang tinggi, sehingga dapat dimanfaatkan sebagai suplementasi dalam ransum (Rusmana dkk., 2008 ).

Berdasarkan uraian diatas perlu dilakukan penelitian mengenai potensi dedak padi yang difermentasi dengan enzim fitase dalam pakan basal terhadap kolesterol total darah pada ayam petelur.

\section{METODE}

Penelitian ini telah dilaksanakan di kendang hewan coba fakultas kedokteran hewan universitas airlangga, selama 5 minggu.

Materi yang digunakan dalam penelitian ini yaitu 24 ekor ayam petelur umur 48 minggu strain ISA Brown. Dedak padi difermentasi dengan enzim fitase $6 \%$ dari jumlah dedak padi yang digunakan. Dedak padi fermentasi disubstitusikan dalam ransum dengan persentase berbeda pada tiap perlakuan yaitu P1 (5\%), P2 (10\%), P3 (15\%), dan P4 (20\%). PO(-) merupakan kontrol negatif dan $\mathrm{PO}(+)$ merupakan kontrol positif. Minyak ikan lemuru 2\% 
disuplementasikan pada perlakuan $\mathrm{PO}(+)$ hingga P4. Semua pakan perlakuan dibuat iso protein dengan kandungan protein kasar berkisar $18,22 \%$. Air minum diberikan secara ad libitum yang ditambah dengan Vitachik untuk mengurangi stress pada ayam. Penggunaan konsentrat ayam petelur 124P dengan kandungan protein 30$32 \%$ dari PT. Charoen Pokphand. Enzim fitase diperoleh dari koloni tunggal isolate rumen yaitu Actinobacillus sp. dan Bacillus pumilus yang didapat dari laboratorium proteomic Institute Tropical Disease Universitas Airlangga. Sedangkan minyak ikan lemuru diperoleh dari distributor Surabaya. Alkohol 70\% sebagai antiseptik dari apotek di Surabaya

Alat yang digunakan dalam penelitian ini adalah peralatan untuk pembuatan pakan, timbangan digital, kandang baterai yang terbuat dari kayu dan bambu, tempat pakan dan minum yang terbuat dari plastik dan alat pembersih kandang. Pengambilan sampel darah menggunakan spuit $3 \mathrm{cc}$ dan needle $23 \mathrm{G}$, tabung darah tanpa antikoagulan untuk mendapatkan serum dan alat Chemical Analizer Midray BS-220E untuk analisis kolsterol.

Penelitian ini merupakan penelitian eksperimental, rancangan penelitian yang digunakan adalah Rancangan Acak Lengkap (RAL). Percobaan dilakukan dengan enam perlakuan dengan empat ulangan pada setiap perlakuan.. Penelitian terdiri dari dua periode yaitu periode adaptasi, dan periode perlakuan. Pada periode adaptasi ternak diberi pakan komersial ayam petelur selama satu minggu. Pemberian pakan perlakuan dimulai pada periode perlakuan. Periode perlakuan dilakukan selama 30 hari.

Pengambilan sampel dilakukan pada hari ke-30 perlakuan. Ayam petelur di puasakan selama 24 jam. Daerah suntikan disterilkan menggunakan alcohol 70\%. Sampel darah diambil dari vena brachialis ayam menggunakan syringe $23 \mathrm{G}$ sebanyak 2cc. Darah yang telah diambil ditempatkan pada tabung darah tanpa antikoagulan dan di diamkan hingga terbentuk serum. Serum yang didapatkan di analisis menggunakan Chemical Analizer Midray BS-220E.

Data yang telah didapatkan akan dianalisis statistik menggunakan Analysis of Variance (ANOVA) kemudian dilanjutkan dengan uji jarak bergada dari Duncan.

\section{HASIL DAN PEMBAHASAN}

Data hasil penelitian potensi dedak padi yang difermentasi dengan enzim fitase terhadap kolesterol total darah pada ayam petelur disajikan pada Tabel 1.

Table 1. Rata-rata dan standart deviasi kadar kolesterol total darah

\begin{tabular}{cc}
\hline Perlakuan & $\begin{array}{c}\text { Rata-rata kadar } \\
\text { kolesterol total darah } \\
\text { ayam petelur } \pm \text { SD } \\
\text { (mg/d1) }\end{array}$ \\
\hline P0(-) & $110,00 \pm 6,083^{\mathrm{c}}$ \\
P0(+) & $100,75 \pm 7,932^{\mathrm{ab}}$ \\
P1 & $98,50 \pm 9,469^{\mathrm{ab}}$ \\
P2 & $94,33 \pm 3,786^{\mathrm{a}}$ \\
P3 & $94,25 \pm 10,532^{\mathrm{a}}$ \\
P4 & $93,50 \pm 11,561^{\mathrm{a}}$ \\
\hline
\end{tabular}

Berdasarkan analisis data dengan one way ANOVA tidak terdapat perbedaan yang nyata $(p>0,05)$ pada perlakuan. Pada Uji lanjutan dengan Duncan terdapat perbedaan antara PO() (5\%) dengan $\mathrm{PO}(+), \mathrm{P} 1$ (5\%), $\mathrm{P} 2(10 \%)$, P3 (15\%), dan P4 (20\%), namun $\mathrm{PO}(+)$ tidak berbeda nyata dengan $\mathrm{P} 1, \mathrm{P} 2$, dan P3 dan P4 Hasil rata-rata kadar kolesterol total, darah pada tabel diatas menunjukkan bahwa niai rata-rata kadar kolesterol total darah tertinggi pada $\mathrm{P0}(-)$ yaitu sebesar $110,00 \mathrm{mg} / \mathrm{dl}$ selanjutnya $\mathrm{PO}(+)$ sebesar $100,75 \mathrm{mg} / \mathrm{dl}$, P1 sebesar 98,50 mg/dl, P2 sebesar 
94,33 mg/dl, P3 sebesar 94,25 mg/dl dan rata-rata yang terendah pada $\mathrm{P} 4$ yaitu sebesar 91,90 mg/dl. Menurut Manoppo et al (2007) kadar kolesterol total darah ayam normal adalah sekitar 52- $148 \mathrm{mg} / \mathrm{dl}$. Hal tersebut menunjukkan bahwa pada masingmasing perlakuan memiliki kadar kolesterol total yang normal.

Tidak adanya perbedaan nyata pada kadar kolesterol total karena dapat diketahui bahwa 15\% kadar kolesterol dihasilkan oleh luar tubuh (makanan) dan 85\% dihasilkan secara endogen (Jim, 2013). Avianti dkk (2014) menjelaskan bahwa pakan yang diserap usus mengandung komponen antara lain karbohidrat, lemak, protein dan lain lain. Zat tersebut dipecah menjadi senyawa yang lebih sederhana kemudian melewati vena porta hepatika atau sistem limfatik menuju ke hati, kemudian diubah menjadi asetil KoA. Asetil KoA diubah menjadi senyawa trimester enam karbon 3-hidroksi3metilglutaril CoA (HMG-CoA). Enzim HMG-CoA reduktase berperan dalam mengubah ß-OH-ß-metilglutaril CoA menjadi asam mevalonate. Tingkat kedua melibatkan perubahan HMG CoA menjadi skualen, suatu hidrokarbon asiklik yang mengandung 30 atom karbon. Tingkat ketiga skualen dijadikan siklik dan diubah menjadi sterol dengan 27 atom karbon (kolesterol). Kolesterol dikeluarkan dari tubuh ketika dikatabolisme dan disekresi dalam garam empedu yang akhirnya diekskresi melalui feses (Jim, 2013).

Kadar kolesterol dipengaruhi oleh pembentukan kolesterol secara endogen karena kolesterol sangat dibutuhkan pada ayam petelur dalam jumlah banyak untuk membentuk hormon steroid (Lestari dkk, 2017). Namun pada uji jarak berganda dari Duncan menunjukkan adanya perbedaan antara kelompok kontrol dengan perlakuan
Menurut SNI (2006) pakan ayam petelur umur 20 minggu sampai dengan masa afkir mengandung serat kasar maksimum 7,0 \% dalam ransum. Kandungan serat kasar dalam ransum perlakuan yaitu $\mathrm{PO}(-)$ sebesar $5,17 \%$, $\mathrm{PO}(+)$ sebesar 6,09 \%, P1 sebesar 6,28\%, P2 sebesar 6,53 \%, P3 sebesar 7,56\%, dan P4 sebesar 8,07 \%. Hal ini menunjukkan bahwa kandungan serat kasar dalam ransum perlakuan PO(-) sampai P4 semakin meningkat. Pemberian pakan berserat tinggi dapat menurunkan kadar kolesterol. Rendahnya kandungan kolesterol yang diberi perlakuan ransum serat kasar diduga karena serat yang terdapat dalam ransum dapat mengurangi sekresi dari kelenjar empedu, untuk mengurangi produksi asam-asam empedu yang menyebabkan penurunan absorbsi dari asam-asam lemak dan kolesterol dalam tubuh. (Joseph dkk., 2002). Lemak makanan yang dimakan dalam usus dicerna oleh enzim pancreas dan diemulsikan oleh garam empedu menjadi micelles atau kilomikron. Micelles, inilah yang diserap oleh tubuh sebagai sumber tenaga, bahan dasar pembentuk kolesterol yang kemudian didefositkan pada bagian organ tubuh tertentu seperti telur (Witariadi dkk., 2014).

Enzim fitase yang mampu

mendegradasi fitat dalam saluran pencernaan untuk menghasilkan mioinositolfosfat, inositol dan fosfor anorganik (P). Suplementasi enzim fitase dalam ransum dapat meningkatkan kecernaan bahan kering, lemak kasar, $\mathrm{P}, \mathrm{Zn}, \mathrm{Mg}$, dan $\mathrm{Cu}$, (Lim et al., 2001). Kadar mineral anorganik dalam suatu bahan pakan berkaitan dengan kadar abu yang merupakan zat anorganik sisa hasil pembakaran suatu bahan organik. Pengabuan dilakukan untuk menentukan jumlah mineral yang terkandung dalam bahan. Penentuan kadar mineral bahan secara asli sangatlah sulit sehingga perlu 
dilakukan dengan menentukan sisa hasil pembakaran atas garam mineral bahan tersebut (Kaderi, 2015).

Lamid et al., 2018 menyatakan bahwa penggunaan dedak padi berenzim fitase dan minyak lemuru pada pakan ayam petelur dapat menurunkan kadar kolesterol pada daging. Kadar kolesterol daging dan telur sebanding dengan kadar kolesterol darah (Rahmat dan Rachmat, 2011). Penelitian Witariadi dkk (2014) melaporkan bahwa suplementasi 0,30\% enzim Phylazim yang merupakan campuran beberapa enzim, yaitu enzim phytase, amilase, dan proteinase dalam ransum yang menggunakan dedak padi menurunkan kadar serum kolesterol darah ayam. Kandungan lipase dalam enzim Phylazim mampu mendegradasi lemak menjadi asam lemak dan gliserol. Asam lemak masuk kedalam siklus Krebs, sehingga menghasilkan energi yang digunakan untuk memecah asam amino dengan bantuan enzim protease yang berguna untuk mensintesa protein telur. Protein merupakan komponen utama untuk sintesis daging dan telur. Enzim lipase mampu meningkatkan energi metabolis dedak padi, sehingga mampu meningkatkan penggunaan dedak padi dalam ransum. Adanya enzim fitase dalam ransum yang dapat meningkatkan retensi mineral kalsium, fosfor, dan mangan ( Piao et al., 1999).

Penggunaan minyak ikan lemuru pada ransum ayam petelur dapat menurunkan kadar kolesterol total serum dan telur. Minyak ikan lemuru banyak mengandung asam lemak omega 3 yaitu Eicosapentaenoic Acid (EPA) dan Docohexaeenoid Acid (DHA). Asam lemak omega 3 menekan sintesis trigliserida dan apolipoprotein B, meningkatkan penghilangan VLDL oleh jaringan perifer atau hati serta meningkatkan ekskresi empedu dalam ekskreta (Newman, 2002). Musa dkk (2009) dalam Lokapirnasari dkk (2018) menyebutkan bahwa penurunan kolesterol disebabkan adanya peningkatan high density lipoprotein (HDL) dan penurunan low density lipoprotein (LDL) serta VLDL dalam serum.

\section{KESIMPULAN}

Pemberian dedak padi yang difermentasi dengan enzim fitase dalam pakan basal cenderung menurunkan kolesterol total darah pada ayam petelur.

\section{DAFTAR PUSTAKA}

Aviati V., Siti M. M., Tyas Rs. 2014. Kadar Kolesterol Telur Puyuh Setelah Pemberian Tepung Kunyit Dalam Pakan. 58-64.

Badan Standar Nasional.2006. Pakan Ayam Ras Petelur. SNI 01-39282006.

Direktorat Jendral Peternakan dan Kesehatan Hewan Kementrian Pertanian. 2017. Statistik Peternakan dan Kesehatan Hewan.

Jim. L. E. 2013. Metabolisme Lipoprotein. Jurnal Biomedik (JBM). 5(3): 149-156.

Joseph G,. Uhi HT., Rukmiasih, Wahyuni I., Hafid H., Parakkasi A., 2002. Status Kolesterol Itik Mandalung dengan Serat Kasar dan Vitamin E.

Kaderi, H. 2015. Arti Penting Kadar Abu pada Bahan. http://balittra. litbang.pertanian.go.id/ diakses pada 20 Maret 2019.

Lim ,H.S., H. Namkung, J.S Um.,K.R kang, B.S. Kim and I. K. Paik. 2001. The Effect of Phytase Suplementation on the Perfomans of Broiler Chicken Feed Diet with Different Levels of Non- 
Phytase Phosporus. Asian-Aust. J Anim. Sci 14(2): 250-257.

Lamid M., Puspaningsih N. N. T., Asmarani O. 2014. Potential of Phytase Enzymes as Biocatalyst for Improved Nutritional Value of Rice Bran for Broiler Feed. J. Appl. Envron. Biol. Sci. 4(3) 377-380.

Lamid M. A., Al-Arif., S.H. Warsito. 2018. Phytase Enzyme and Lemuru (Sardinella) Oil Suplementation in Layer Feed For Improving Meart Quality. Faculty of Veterinary Medicine. Airlangga University.

Lestari, I. L., A. Widigdyo, A. N.O. Ari K. 2017.Pengaruh Penambahan Kayu Secang (Caesalpinia sappan L.) Dan Minyak Ikan Lemuru Sebagai Aditif Pakan Terhadap Daya Simpan Telur dan Kolesterol Telur. Jurnal Aves. 11(2):38-44.

Lokapirnasari, W.P., Sinin A., Bijianti, R., 2018. The Decrease of Cholesterol Levels on Broiler Meat by The Addition of Crude Fish Oil.

Manoppo, M. R. A., R. Sugihartuti, T.S. Adikara dan Y. Dhamayanti. 2007. Pengaruh Pemberian Crude Chrorella terhadap Total Kolesterol Darah Ayam Broiler. Fakultas Kedokteran Hewan. Universitas Airlangga.

Murray,R.K, D.A Bander, K.M Botan, P.J. Kenelly, P.A Weil, and V.W Rodwell. 2012. Harper's Illustrated Biochemistry.The mc Graw -Hill Companies. Inc. USA.

Musa, H.,G.H. Chen, J.H. Cheng., G.M. Yousif. 2007. Relation between Abdominal Fat and Serum Cholesterol, Trygliserides, and Lipoprotein Concentrations in Chicken Breeds. Turk. J. Vet. Anim. Sci., 31(6): 375-379. Tubitak.
Natsir M.H., Widodo E., Sjofjan O. 2017. Industri Pakan Ternak. UB Press. Malang. 64-65.

Newman, R. E., Bryden, W.L., Fleck, E., Ashes, J., Buttemer, W. A., Storlien, L. H., Downing, J. A. 2002. Dietary n3 and n-6 fatty acids alteravian metabolism: metabolism and abdominal fat deposition. Br. J. Nutr. 88: $11-18$.

Piao, X.S.,I.K. Han,J.H., Kim, W.T. Cho, Y.H. Kim , and C.Liang. 1999. Effects of Kemzyme, Phytase, and Yeast Supplementation on The Growth Performance and Pullution Reduction of Broiler Chicks. Asian-Aust. J. Anim. Sci.12(1):36-41.

Reddy, N.R., S.K. Shate and D.K Shalunke. 1982. Phytase in Legumes and Cereals. Advances in Food Research. 28 1-75.

Rahmat D. dan R. Wiradimaja. 2011. Pendugaan Kadar Kolesterol Daging dan Telur Berdasarkan Kadar Kolesterol darah pada Puyuh Jepang. Jurnal Ilmu Ternak. 11 (1) : 35-38.

Rusmana, D. 2008. Minyak Ikan Lemuru Sebagai Imunomodulator dan Penambahan Vitamin E untuk Meningkatkan Kekebalan Tubuh Ayam Broiler. [disertasi]. Bogor. Sekolah Pascasarjana. InstitutPertanian Bogor.

Wahju, J. 2004. Ilmu Nutrisi Unggas. Gadjah Mada University Press. Yogyakarta.

Wijaya,V. Graha, Ismoyowati, dan D.M. Saleh. 2013. Kajian Kadar Kolesterol dan Trisliserida Darah Berbagai Itik Lokal yang Pakannya Disuplementasi dengan Probiotik. JIP 1(2):661-668. 
Journal of Basic Medical Veterinary Nurfitri et al.

Witariadi N. M.. Roni N G K.,Utami P I A. 2014. Penammbahan Enzim Kompleks dalam Ransum Berbasis Dedak Padi terhadap Produksi Kadar
Desember 2020, Vol.9 No.2, 92-98 Online pada https://e-journal.unair.ac.id/JBMV
Kolesterol Telur Lohman Brown. Majalah Perternakan 17(3):107-112. 